\title{
The Role of Lawyer-Legislators in Shaping the Law: Evidence from Voting on Tort Reforms
}

\author{
Ulrich Matter University of Basel \\ Alois Stutzer University of Basel
}

\begin{abstract}
Attorneys elected to the US Congress and to state legislatures are systematically less likely to vote in favor of tort reforms that restrict tort litigation but more likely to support bills that extend tort law than are legislators with different professional backgrounds. This finding is based on the analysis of 64 roll call votes at the federal and state levels between 1995 and 2014. It holds when controlling for legislators' ideology and is particularly strong for term-limited lawyer-legislators. The empirical regularity is consistent with the hypothesis that lawyer-legislators, at least in part, pursue their private interests when voting on tort issues. Our results highlight the relevance of legislators' identities and individual professional interests for economic policy making.
\end{abstract}

\section{Introduction}

There are many lawyers in US legislatures. This raises a serious agency issue in a representative democracy when they draft and reform law that affects their profession. The issue is more general though and refers to the question of whether and how professional backgrounds of legislators are to play a role in state policy making. This is an important aspect of how political selection might matter for

\footnotetext{
We are grateful to three anonymous reviewers, Thomas Braendle, Tyler Cowen, Reiner Eichenberger, Bruno Frey, Robin Hanson, Thorsten Henne, Jonathan Klick, Margaret Kyle, David Laibson, Simon Luechinger, Mark Miller, Florian Neumeier, Reto Odermatt, Catherine Sharkey, Michaela Slotwinski, Michael Stone, Thomas Stratmann, and Alexander Tabarrok; conference participants at the 2013 meeting of the Comparative Law and Economics Forum, the 2013 European Public Choice Society meeting, the 2013 Centre for European Economic Research conference, the 2013 congress of the European Economic Association and the Econometric Society European Meeting, and the 2014 meeting of the Verein für Socialpolitik; and seminar participants at George Mason University and the University of Basel for helpful remarks. We also thank Joerg Kalbfuss for excellent research assistance. Matter acknowledges financial support from the WWZ Forum.
}

[Journal of Law and Economics, vol. 58 (May 2015)]

(C) 2015 by The University of Chicago. All rights reserved. 0022-2186/2015/5802-0012 $\$ 10.00$ 
economic policy. ${ }^{1}$ Insights are important to inform the choice of institutions that govern the representation of interests in politics such as ethics laws, recusal and disclosure rules, and incompatibility regimes.

We concentrate on lawyers ${ }^{2}$ holding a seat in the legislature, so-called lawyerlegislators, for several reasons. They form one of the most prominent groups, as they often hold many seats (around one-third of members in the House of Representatives have professional backgrounds as attorneys). They are, with few exceptions, members of the same professional associations (the American Bar Association and, in the case of trial lawyers, the American Association for Justice). Moreover, they are experts on law, their political mandate is complementary to their business activity, and-importantly-they are involved in drafting rules that, depending on their design and implementation, generate more or less demand for legal services.

An important area is tort law, where lawyer-legislators face a conflict of interest. In particular in the United States, where estimates of the total transactions generated by the tort law system amounted to $\$ 265$ billion in 2010, which is equal to 1.82 percent of gross domestic product (Towers Watson 2012), attorney fees account for a large part of that, with estimates of 30 percent or higher. ${ }^{3}$ Plaintiffs' lawyers and defense lawyers have a vital interest in preserving this system. In the literature on US tort reform, it has been argued that lawyer-legislators try to block reforms that are meant to simplify and limit the scope of liability rules or restrict damages (see, for example, Epstein 1988; Zywicki 2000; Rubin 2005). However, no systematic empirical evidence supports this claim. A related literature focuses on the dynamics of tort reforms and the drivers of certain types of reforms in the aggregate (Klick and Sharkey 2008; Miceli and Stone 2013) but omits interests specific to lawyers.

In this paper, we analyze whether lawyer-legislators are more likely than legislators with different professional backgrounds to vote against tort reforms aimed at a reduction of the number and the size of tort cases. We do this by studying the voting behavior in Congress and 17 state legislatures between 1995 and 2014 . The empirical analysis is based on a custom-made data set that we compiled using new computational techniques to draw information from the rich online resource from Project Vote Smart. We conduct the analysis separately for the federal and the state levels. On the basis of the econometric analysis of 14 votes on

\footnotetext{
${ }^{1}$ An introduction to the economic analysis of political selection is provided in Besley (2005). Analyses for specific professional groups focus on businessmen (Gehlbach, Sonin, and Zhuravskaya 2010) and public servants (Braendle and Stutzer 2010,2011). This research pursues a positive analysis, complementing older work (for example, Luce 1924) on the overrepresentation of specific professional groups.

${ }^{2}$ Our definition of a lawyer in this study is based on the professional background of a person and not only on his or her education. Someone who holds a degree from a law school but has never practiced law is not counted as a lawyer.

${ }^{3}$ Estimates by the US Council of Economic Advisers (2004) are around 30 percent. However, when the benchmark for privately negotiated contingency fees of around one-third with "significant variation up and occasional variation down" (Eisenberg and Miller 2004, p. 35) and the additional defense costs are taken into account, 30 percent is a lower bound for the total fraction of tort fees going to lawyers.
} 
tort reform legislation, we find that the probability that attorneys at the federal level vote in favor of reforms is 7.3 percentage points lower than that of legislators with different professional backgrounds, ceteris paribus. Using 38 votes at the state level, we find that the probability for lawyer-legislators is 6.9 percentage points lower than for legislators with different professional backgrounds. At the federal level, the effect is slightly more pronounced for attorneys belonging to the Democratic Party than for those belonging to the Republican Party. In general, Republicans are more likely than Democrats to support reform bills that restrict liability. Finally, our analysis allows us to contribute to the question of whether the gender of legislators matters for the design of tort law. This question considers the suggested disproportionally negative impact of certain types of tort reforms on women (see Section 2). Indeed, female federal legislators are less likely than their male colleagues to support tort reforms that restrict liability, ceteris paribus.

In supplementary tests, we address a series of alternative explanations. First, we examine whether attorneys in politics consistently vote differently from nonattorneys. We find neither evidence for a systematic and distinctive voting pattern in a repeated random sample of votes on issues other than tort nor evidence that voting behavior can be explained by ideological differences using legislators' roll call records. Second, we investigate whether lawyer-legislators' voting behavior caters to specific preferences of their electorate instead of being motivated by private interests. We do not find evidence for this refined median-voter hypothesis. Restricting the sample to narrow races with one attorney candidate and one nonattorney candidate, we find a voting pattern similar to the overall pattern. Moreover, legislators in the House of Representatives who compete against attorneys in electoral races are not more likely to oppose restricting tort reforms than are legislators who face competitors with any other professional background. For a restricted sample of votes at the state level, we find some support that electoral incentives matter. Lawyer-legislators who face a binding term limit are more likely to vote in favor of an extension of tort law than are lawyer-legislators who can be reelected.

Throughout this study we conduct a positive politicoeconomic analysis. Therefore, our contribution should not be interpreted as an assessment of the tort reform process from a welfare perspective. We do not discuss what kind of tort law regime might be preferable for citizens. We rather uncover microevidence on the underlying forces that are driving the tort reform process and shape law in general.

This paper is organized as follows. In Section 2, we first review the arguments that emphasize the role of lawyers in legislatures. We then derive the political economy hypothesis that lawyer-legislators are more likely than legislators with different professional backgrounds to oppose tort reforms. Section 3 describes the prerequisites for our empirical analysis: the data and the empirical strategy. The results for voting behavior at the federal and state levels are presented in Section 4 . Section 5 offers concluding remarks. 


\section{Lawyer-Legislators' Interests in Tort Reforms}

\subsection{Lawyers in Legislatures}

General sentiments about lawyer-legislators differ widely. On the one hand, there are concerns about the presence of lawyers in government going as far back as medieval England, where attorneys were temporarily banned from Parliament "because of their interest and activity in stirring up lawsuits" (Warren 1911, p. 25; quoted in Roth and Roth 1989, p. 31). On the other hand, having legal skills is obviously an advantage when making laws. This is particularly the case for attorneys who hold offices or are members of committees related to the judicial system, as pointed out by Hain and Piereson (1975). Moreover, lawyers and politicians are members of the so-called talking professions (Norris and Lovenduski 1995); hence, a law school graduate's rhetorical skills are clearly advantageous in politics.

The presence of lawyers in legislatures is especially prominent in the United States. Around one-third of the members in the US House of Representatives have professional backgrounds as attorneys, whereas the share of lawyerlegislators across state legislatures varies between 5 and 25 percent (in 2011; see Figure B1 in the online appendix).

The significant presence of attorneys in US politics has attracted the attention of the social sciences at least since de Tocqueville (1838, p. 260), who describes the lawyers in America as "the only enlightened class whom the people do not mistrust, [which is why] they are naturally called upon to occupy most of the public stations. They fill the legislative assemblies and are at the head of the administration; they consequently exercise a powerful influence upon the formation of the law and upon its execution." More recent work on lawyer-legislators focuses on their personal characteristics and attitudes as well as their motives for entering politics. ${ }^{4}$ On this basis, several theoretical suggestions concerning lawyer-legislators' behavior and capabilities in office have been put forward. A prominent theory proposes that many lawyers already have a political career in mind when they choose to go to law school. They are aiming at high positions in the government or public services and enter the legislature to start their careers (Podmore 1977). This perspective suggests that lawyer-legislators act close to the preferences of their parties and the electorate to enhance their political careers. An opposing view comes from Schlesinger (1957), who argues that attorneys enter politics only for a short time period in order to boost their careers in private law practice. According to this perspective, lawyer-legislators are more likely than other legislators to act according to the policy preferences of the legal profession and/or the clients they are representing. Graves's (1946) observation,

\footnotetext{
${ }^{4}$ Note that in this literature the term "lawyer-legislator" is sometimes used in a broader sense than how we define it. In the literature overview presented here, "lawyer-legislator" does, therefore, not exclusively refer to the professional background of a legislator. It might also refer to her or his educational background. However, we think that the theoretical arguments discussed in this section also hold for our more restrictive definition of a lawyer-legislator.
} 
that lawyer-legislators are too busy dealing with their legal services businesses to focus on important legislative matters, supports this point of view.

Other prevalent theories about lawyer-legislators' behavior focus on a formative education at law schools and specific professional skills. Hyneman (1940, p. 569) sees the attorney as an "accepted agent" of all political groups of the American people who represents the citizens in legislature in the same manner as clients in court. In a similar vein, Derge (1959, p. 432) describes the lawyer-legislator as an "intellectual jobber and contractor." However, Derge also points out that the lawyer-legislator's clients come from special interest groups rather than the public in general. According to Graves (1946), the legal training at law schools makes lawyer-legislators rather conservative and likely to defend the status quo. Miller (1995, p. 27) adds that legal training leads to a strong "rule and rationality orientation" that might threaten the political substance of lawyer-legislators' work in office.

Unlike previous work on lawyer-legislators, we apply a political economics perspective. Lawyer-legislators-as all politicians-have individual preferences and goals that they pursue given their scope of action. Discretionary leeway in politics thereby emerges if reputation mechanisms are incomplete and no binding election promises are possible. To the extent that citizens do not fully know candidates' preferences and positions on specific policy issues because these positions are secondary or not salient, ${ }^{5}$ voters cannot optimally elect policies as modeled in the citizen-candidate framework (see Osborne and Slivinski 1996; Besley and Coate 1997). Instead, politicians' individual preferences become key determinants of policy choices (for evidence in Senate roll call votes, see Levitt 1996). This might involve their ideals of a productive law as well as more mundane private advantages. As one aspect, lawyer-legislators might thus keep an eye on the prospects of increasing their expected incomes.

All members of a legislature can, of course, engage in politics catering to special interest groups with a view to receiving personal benefits in return (future earnings or financial support for their campaigns). However, lawyer-legislators' private interests (in line with the interests of the legal services industry) are particularly linked to the design of the law. Attorneys in the legislature can directly, and in various ways, influence the basis of their outside and future earnings. ${ }^{6}$ Some legislation has an influence on the demand for legal services, while other legislation directly influences the prices of legal services (for a general account of the market for lawyers, see Hadfield 2000). The former refers to rules that provide incentives to resolve disputes in court and/or generate the need for legal advice in order to avoid becoming involved in litigation in the first place. A simple exam-

\footnotetext{
${ }^{5}$ More recent work on the role of secondary policy issues and salience in election models include Besley and Coate (2003) and List and Sturm (2006).

${ }^{6}$ Recently, politicians' outside earnings and the trade-off with engagement in legislative work has received a lot of attention in political economics research. Theoretical considerations are formulated in Caselli and Morelli (2004), Besley (2005), and Mattozzi and Merlo (2008). Empirical evidence concerning politicians' compensation, outside earnings, and effort in office is presented in Gagliarducci, Nannicini, and Naticchioni (2010).
} 
ple of this would be where the legal code is overly complex, provides numerous opportunities to litigate against natural or legal persons, and leads to substantial information asymmetry between attorneys and their clients (on complexity see, for example, White 1992). High prices for legal services can be achieved either directly by setting them by law or indirectly by easing antitrust laws to facilitate price fixing. ${ }^{7}$ Other drivers of prices are the procedural rules that define the extent to which attorneys are free to set up contingency-fee agreements.

\subsection{Lawyer-Legislators and Tort Reforms}

Many of the rules that have a considerable impact on the demand for legal services can be found in US tort law. The tort system has doubtless become big business for many lawyers ( $\$ 265$ billion in 2010). Whether the system is also beneficial to consumers is discussed, and tort law has almost constantly been under reform pressure since the early 1980s (Sugarman 2002). In fact, by 2012 almost all state legislatures had passed one or several bills to change their mainly commonlaw-based law of torts. More recently, tort reform has also become a federal issue, with several bills being passed by the House of Representatives. ${ }^{8}$ The majority of tort reforms aim to reduce the number of tort suits and the amount of damages awarded. Avraham (2007), investigating the effect of six different types of tort reforms on medical malpractice settlement payments, shows that some reforms indeed reduce the number of annual payments while others reduce average awards. The reforms thus reduce the demand for certain legal services, as suing becomes less attractive, and in some cases also reduce their price either directly by restricting contingency-fee agreements or indirectly by reducing potential contingency fees through damage caps. Lawyers' associations clearly oppose these reforms (Rubin and Bailey 1994; Rubin 2005), and lawyer-legislators might be loyal representatives of such special interest groups. The reforms also potentially reduce lawyer-legislators' outside and future income, in particular if they are not fulltime legislators. But even full-time members of the US House of Representatives are likely to be affected by such reforms through their potential future income, taking into account that they are often elected for only 2 years. In addition, lawyers as full-time legislators are likely to have close ties with colleagues in the legal

\footnotetext{
${ }^{7}$ Fixing prices for legal services is not unknown in the United States. Until the 1970s, the American Bar Association had been recommending minimal fees to its members. In 1974, the Supreme Court judged that practice to be price fixing and therefore a violation of the Sherman Act (Handberg 1976).

${ }^{8}$ Whether this reform process is indeed transforming the US tort system into a regime that is more beneficial for consumers is a controversial issue in the law and economics literature. If any opinions of scholars can be discerned, they are, at least in the early phase of the reform process, rather in favor of tort reforms (see Shapiro 1991). Aspects of tort liability are still controversially discussed by leading scholars without a clear consensus (see, for example, the prominent discussion about product liability in the Harvard Law Review between Polinsky and Shavell [2010a, 2010b] and Goldberg and Zimpursky [2010]). In this study, we do not discuss which type of tort system is preferable from a welfare perspective. It is important to note, however, that given the state of the literature, lawyer-legislators (although experts in the law) are not expected to have superior knowledge. It is thus rather unlikely that lawyer-legislators vote systematically differently from other legislators.
} 
profession and/or be co-owners of a law firm. Attorneys in legislatures therefore have an incentive to prevent such reforms. They have many ways to do so. They can oppose or weaken tort reform legislation in the judiciary committee of their legislature. Another option is to actively organize opposition to the proposed bill, if necessary including logrolling. The most obvious action is to vote against it. Since the latter action is clearly observable, we propose the following hypothesis to empirically test the theoretical considerations.

Hypothesis 1. Legislators with professional backgrounds as attorneys vote against tort reforms that aim to reduce the number of suits and the amount of damages awarded with a higher probability than the average legislator with a different professional background.

In the few cases in which a bill on tort reform extends the liability, we expect, using the same theoretical considerations, lawyer-legislators to support it in the interest of their businesses.

The existing literature on lawyer-legislators' voting behavior focuses on their educational backgrounds and does not directly test political economy hypotheses. It rather explores differences in voting behavior between lawyers and other legislators across a broad range of issues without reaching a consistent conclusion. ${ }^{9}$

\subsection{Partisan Considerations and Women in the Legislature}

With regard to voting on tort reform bills, the professional background of legislators is of course not the only relevant factor. First, there is party affiliation. It has been argued that tort reform has become a highly partisan issue, with the Republicans defending the interests of the business community in favor of reforms and the Democrats being pro-plaintiff and against reforms (Sugarman 2002). However, historically and ideologically the parties' positions regarding tort reform are not clear (Sugarman 2006). According to Zywicki (2000), the Democrats' opposition to such reforms can partly be explained by generous campaign contributions from trial lawyers. Anecdotal evidence suggests, furthermore, that lawyer-legislators in the Democratic Party tend to be trial lawyers, whereas Republican lawyer-legislators tend to be defense lawyers. We take this aspect into account by restricting the sample in some analyses to Democrats or Republicans only.

\footnotetext{
${ }^{9}$ On the one hand, Dyer (1976) finds only a relatively small difference between lawyers and nonlawyers in voting on no-fault insurance proposals in four state legislatures, while Engstrom and O'Connor (1980) find lawyer-legislators to be more supportive than nonlawyers of reforms that strengthen the legislative branch of government. On the other hand, Derge $(1959,1962)$, investigating votes on bills concerning different social and economic issues in three state legislatures, finds no evidence of a systematically different voting behavior among lawyer-legislators and generally no tendency for lawyer-legislators to vote cohesively. Green et al. (1973, p. 450) investigate the voting behavior of lawyers in Congress on issues related to the US Supreme Court over the years 1937-68 and conclude in the same vein as Derge that "the legal profession variable is justifiably branded as irrelevant."
} 
Second, the gender of representatives might be of particular importance when studying voting behavior in the context of tort reforms. Research has shown that being a woman matters for policy outcomes and that women in legislatures have different voting patterns than men, especially if the votes are on issues concerning children, families, or women. ${ }^{10}$ Even though tort law does not de jure treat women differently from men, it has been argued that it affects women de facto differently. In particular, scholars have hypothesized that caps on noneconomic damages have adverse effects on women and the elderly (Finley 2004, cited in Sharkey 2005). Women are likely to be awarded less in direct economic damages, because they either do not earn income or earn less. Damages for pain and suffering are therefore crucial for the total amount of damages they can receive. With noneconomic damages capped, attorneys might therefore "disproportionately screen out claims by women," which makes it harder for women to claim any damages (Sharkey 2005, p. 490). Moreover, in the field of medical malpractice tort law, Rubin and Shepherd (2008) find that caps on noneconomic damages have a disproportionately positive effect on the non-motor-vehicle accidental death rates of women relative to those of men. Shepherd (2008) also finds evidence for her hypothesis that restrictions on noneconomic damages and punitive damages disproportionally reduce doctors' care levels for women and that women at the same time benefit less from increases in doctors' activity levels resulting from these reforms. Some of the votes analyzed in this paper concern medical malpractice issues.

\section{Empirical Approach}

\subsection{Data}

To test our hypothesis, we compiled a data set with the records from 64 votes on 48 different bills concerning tort law issues in 17 state legislatures and Congress between 1995 and 2014. ${ }^{11}$ All 14 votes at the federal level concern bills that restrict liability. In that sense, they are typical tort reform bills, aimed at reducing the amount of damage payments and/or the number of tort cases, for example, by introducing caps on noneconomic damages. At the state level, 12 of the 50 votes concern bills that extend the existing tort liability, for instance by removing caps on noneconomic damages. Each voting record consists of a list of all members of the legislature and how they voted. Our dependent variable composed from these

\footnotetext{
${ }^{10}$ See Chattopadhyay and Duflo (2004) for women in politics and policy outcomes and Swers (2001) for an overview of female representatives' behavior in state legislatures and Congress. In addition to the differential voting behavior of female representatives, Washington (2008) shows that, conditional on a congressperson's number of children, having an additional daughter increases the representative's propensity to cast votes that are more liberal, in particular on women's issues.

${ }^{11}$ The states included in our analysis are Arizona, Colorado, Florida, Illinois, Kansas, Louisiana, Michigan, Missouri, Mississippi, North Carolina, New Jersey, Nevada, Oklahoma, Pennsylvania, Tennessee, Utah, and Wisconsin. The choice of these states is due to the data compilation process described in this section. The appendix presents data for all votes used in our study.
} 
voting records is equal to one if the representative voted yes (or pair yes) and zero if he or she voted no (or pair no). ${ }^{12}$

We linked these voting records to biographical information about each representative's professional background, party affiliation, gender, bar affiliation, age, and level of education. We take the latter two pieces of information into account to control for sociodemographic characteristics that are potentially correlated with voting behavior. Thereby, the variable Higher Education captures legislators with a college degree. In addition, we include an indicator variable that is equal to one if the legislator holds a degree from a law school (particularly, a JD, an SJD, an LLM, or an LLB) but neither has been working as an attorney nor is a member of a bar association. The covariates Attorney, Republican, Female, Nonattorney Bar Associate, and Higher Education are also coded as binary indicator variables.

We removed only 12 observations in federal voting records from the data set because of missing biographical data (Table B1 in the online appendix presents a complete accounting of the number of observations per vote). Biographical data for the members of state legislatures often lack dates of birth. We therefore exclude the variable Age in our state-level analyses. ${ }^{13}$ We removed no voting records from the state-level sample because of missing biographical data. The adjusted data set thus consists of 5,255 observations from federal votes and 3,595 observations from state-level votes. These observations involve 1,413 lawyer-legislators in Congress and 383 lawyer-legislators in state legislatures. Table 1 presents some descriptive statistics for the explanatory variables, with votes and then legislators as the unit of observation.

Figure 1 provides a first impression of how the variables of interest are jointly distributed, which indicates support for the basic hypothesis. The width of the cells represents the relative share of the professional background categories, while the height of the cells indicates the proportion of votes in each category. The shading indicates the sign and magnitude of the Pearson residuals, which are used to conduct a $\chi^{2}$ test of independence $(P<2.22 \mathrm{E} 16)$. Federal and state-level votes on restricting reforms are included, and the raw difference in the share of yes votes amounts to -14.08 percentage points $(=47.91$ percent -61.99 percent). In summary, legislators with professional backgrounds as attorneys seem to be less likely to vote yes for reforms that potentially harm the legal services industry.

The finding in Figure 1 is not driven by partisan preferences, namely, that lawyers are primarily Democrats opposing reforms. As reported in Table 2, the difference between lawyer-legislators and other representatives is instead found in both parties and at both levels.

Our data are drawn from Project Vote Smart's website using the open-source

\footnotetext{
${ }^{12}$ Voteless members, such as delegates, and members who abstained from voting are excluded from the data set. Including absentees as legislators favoring the status quo (with the dependent variable equal to zero) does not meaningfully affect the results qualitatively or economically. Details of these alternative analyses are available on request.

${ }^{13}$ However, we also checked for the robustness of the results when including Age and thereby losing observations. The results remained qualitatively the same. Details for these analyses are available on request.
} 
Table 1

Summary Statistics

\begin{tabular}{|c|c|c|c|c|c|c|}
\hline & \multicolumn{3}{|c|}{ Federal } & \multicolumn{3}{|c|}{ State } \\
\hline & No & Yes & Mean & No & Yes & Mean \\
\hline \multicolumn{7}{|l|}{ Vote level: } \\
\hline Attorney & 3,350 & 1,905 & .36 & 2,982 & 613 & .17 \\
\hline Republican & 2,509 & 2,746 & .52 & 1,532 & 2,063 & .57 \\
\hline Female & 4,591 & 664 & .13 & 2,829 & 766 & .21 \\
\hline Higher Education & 584 & 4,671 & .89 & 1,041 & 2,554 & .71 \\
\hline Law Degree ${ }^{a}$ & 5,133 & 122 & .02 & 3,555 & 40 & .01 \\
\hline Nonattorney Bar Associate & 5,146 & 109 & .02 & 3,576 & 19 & .01 \\
\hline Age & & & 54.06 & & & \\
\hline DW-NOMINATE (first dimension) & & & .09 & & & \\
\hline \multicolumn{7}{|l|}{ Legislator level: } \\
\hline Attorney & 2,519 & 1,413 & .36 & 1,813 & 383 & .17 \\
\hline Republican & 1,905 & 2,027 & .52 & 931 & 1,265 & .58 \\
\hline Female & 3,415 & 517 & .13 & 1,700 & 496 & .23 \\
\hline Higher Education & 433 & 3,499 & .89 & 651 & 1,545 & .7 \\
\hline Law Degree ${ }^{a}$ & 3,836 & 96 & .02 & 2,167 & 29 & .01 \\
\hline Nonattorney Bar Associate & 3,847 & 85 & .02 & 2,182 & 14 & .01 \\
\hline Age & & & 54.45 & & & \\
\hline DW-NOMINATE (first dimension) & & & .08 & & & \\
\hline
\end{tabular}

${ }^{\text {a }}$ Not an attorney or member of a bar.

interface pvsR (Matter and Stutzer 2015). ${ }^{14}$ In its online collection Project Vote Smart maintains data on candidates for and officials in public office in the United States, including legislators in Congress and state legislatures. It provides voting records on key votes, which are votes selected by a group of political scientists and journalists from all states. According to its website, the main criteria for this selection are the following:

1. The vote should be helpful in portraying how a member stands on a particular issue.

2. The vote should be clear for any person to understand.

3. The vote has received media attention.

4. The vote was passed or defeated by a very close margin. ${ }^{15}$

Usually all four criteria must be met. ${ }^{16}$ This helps to ensure that the votes we analyze are, in a broad sense, of political relevance. Moreover, the nonpartisan selection procedure of key votes is overseen by academics across the political spectrum and is completely independent of the authors of this study. This ensures that the sample of roll call votes analyzed here is not biased with respect to our

\footnotetext{
${ }^{14}$ The functions used to compile the data through Project Vote Smart's application programming interface (VS API) were written in the R programming language. To make these methods accessible to a broader audience, the R package pvsR, which facilitates the compilation of data from the VS API for scientific analysis, is publicly available (see Matter 2013).

${ }^{15}$ Project Vote Smart, 2015 All Key Votes (http://votesmart.org/bills).

${ }^{16}$ In some cases, exceptions are made, for instance, if the margin was not close but the vote received an unusual amount of coverage in the media.
} 


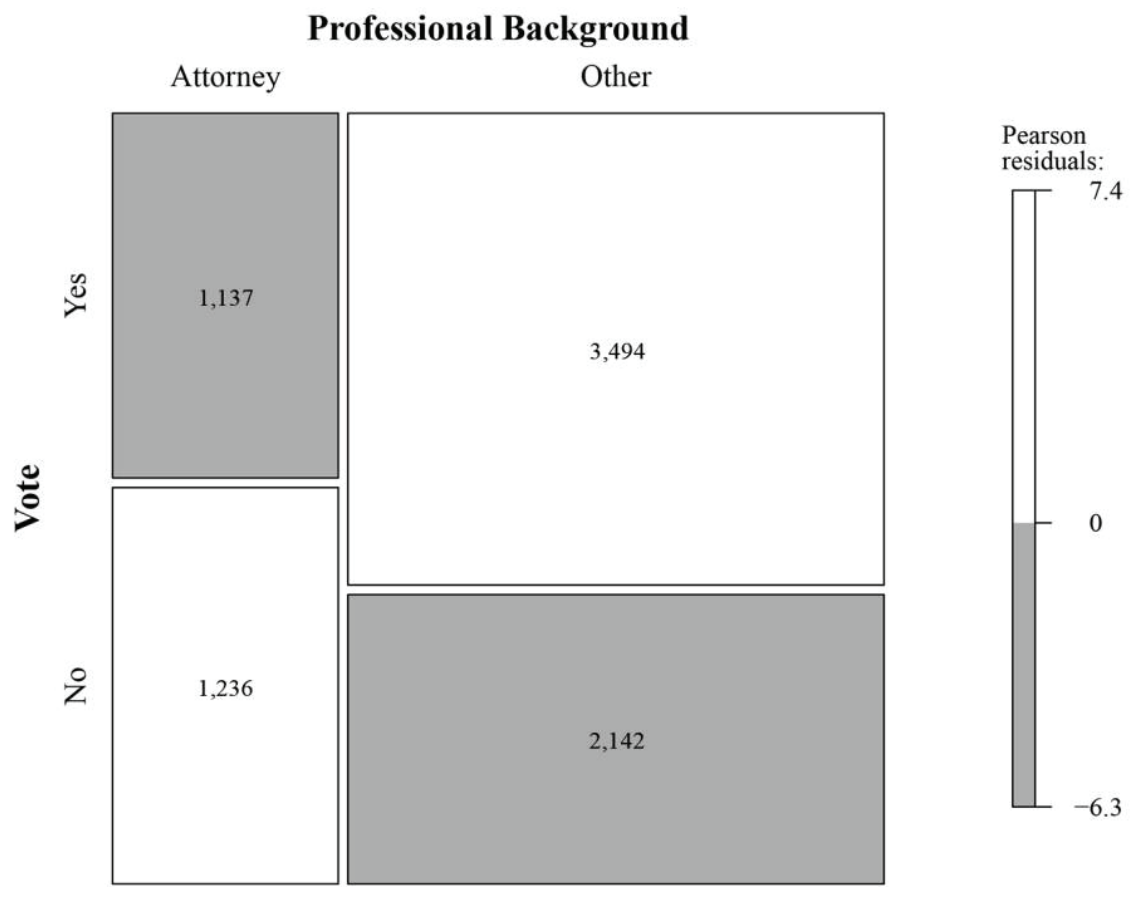

Figure 1. Votes by professional background

hypothesis. In this pool of key bills, we used an algorithm to search each bill's description for tort-law-related terms such as "tort," "product liability," and "medical malpractice." 17 The resulting list of votes was then checked manually to make sure that only votes clearly concerning tort reforms are included..$^{18}$

Legislators' characteristics were extracted from Project Vote Smart's biographical records using a search algorithm similar to that used for the bills' selection. ${ }^{19}$ We coded a representative as having a professional background as an attorney if the section "Professional Experience" mentioned "attorney," "lawyer," "private

\footnotetext{
${ }^{17}$ In particular, we searched each bill's title, described highlights, and synopsis. The search algorithm and the tort-law-related terms can be found in the online appendix (algorithm B1 and Table B2).

${ }^{18}$ In total, 39 votes identified by the automated search process were later removed during a manual check. The main reason for exclusion was that the bill neither limited nor extended tort liability (for example, a bill that revises tax laws for small businesses and thereby also regulates how punitive damages can be taxed). Table B4 in the online appendix presents details about the excluded votes, including the reasons for exclusion.

${ }^{19}$ Biographical data on candidates and officials in Project Vote Smart's candidate profiles are based on a biographical form that each candidate fills out when running in a general election. Candidates or elected politicians can update this biographical form.
} 
Table 2

Support of Tort Reforms: Raw Differences in Voting Behavior

\begin{tabular}{lcccccc}
\hline & \multicolumn{2}{c}{ Federal Votes } & & \multicolumn{2}{c}{ State Votes } \\
\cline { 2 - 3 } \cline { 5 - 6 } & Democrat & Republican & & Democrat & Republican \\
\hline Lawyer-legislators & .06 & .93 & & .08 & .87 \\
Other legislators & .12 & .98 & & .11 & .96 \\
Difference & -.06 & -.05 & & -.03 & -.09 \\
\hline
\end{tabular}

law practice," or "law firm."20 The focus of our empirical analysis is thus on the occupation of attorney and not on the field of study. If a representative obtained a BA or a higher college degree, we define him or her as having a higher level of education. Variables capturing party affiliation, gender, age, bar admission, and law degrees are taken directly from the representatives' biographical records. ${ }^{21}$

Our novel data compilation technique allows us to gain accurate biographical information about hundreds of representatives from different legislatures. This is generally a difficult task, because biographical data usually have several sources, each being differently structured. Furthermore, the method in which the information is collected supports its accuracy, since there are no obvious incentives for representatives to strategically give incorrect information about themselves. The data are easily accessible through the Internet and thus are exposed to screening by political opponents and the media.

\subsection{Empirical Strategy}

We apply different estimation strategies to empirically test our hypothesis. For reasons of simplicity, we mainly present linear probability models estimated with ordinary least squares (OLS) regression. Formally, such a model can be described as

$$
p_{i}=P\left(y_{i}=1 \mid \boldsymbol{x}_{i}\right)=E\left(y_{i} \mid \boldsymbol{x}_{i}\right)=x_{i}^{\prime} \boldsymbol{\beta},
$$

where $p_{i}$ is the probability that representative $i$ votes yes, $y_{i}$ is a dependent variable describing the representative's vote, $\boldsymbol{x}_{i}$ is a vector of explanatory variables describing representative $i$, and $\boldsymbol{\beta}$ is the vector of regression coefficients. As some representatives vote several times in our sample, we use heteroskedasticity-robust standard errors clustered at the individual level to test the statistical significance

\footnotetext{
${ }^{20}$ The search algorithm used to extract information from the biographical records and how it identified lawyer-legislators can be found in the online appendix (algorithm B2 and Table B3). In addition, we systematically improved the coding with extensive manual checks and additional manual coding of special cases.

${ }^{21}$ To determine (using Project Vote Smart's biographical records) whether a legislator with a law degree has never practiced law is in some cases not straightforward (that is, some legislators mention that they are cofounders or partners of a company without mentioning the company's business). We therefore cross-checked our data for all legislators that we identified as having law degrees but neither having professional backgrounds as attorneys nor being bar members. We considered a series of other data sources (such as the legislatures' official websites, their Wikipedia entries, and the websites of firms they founded or worked for according to the biographical records).
} 
of the regression coefficients. ${ }^{22}$ The linear probability model has the advantage of permitting a straightforward interpretation of the coefficients: they can be read as marginal effects of the corresponding variables on the probability of voting yes. Moreover, the interaction effects that we include in some specifications would be difficult to estimate and interpret in a nonlinear model (see Ai and Norton [2003] for a short discussion of the issue). The downside of this approach is that modeling a probability in this manner results in misspecification in the sense that the estimated $\boldsymbol{\beta}$ values might imply probabilities that are greater than 1 or less than 0 . We therefore additionally estimate a logit model in the following form:

$$
p_{i}=P\left(y_{i}=1 \mid \boldsymbol{x}_{i}\right)=F\left(\boldsymbol{x}_{i}^{\prime} \boldsymbol{\beta}\right)=\frac{\exp \left(\boldsymbol{x}_{i}^{\prime} \boldsymbol{\beta}\right)}{1+\exp \left(\boldsymbol{x}_{i}^{\prime} \boldsymbol{\beta}\right)} .
$$

Independently of the estimation approach, we control in a flexible way for the variation in unmeasured characteristics of the constituencies across states by including state dummies in the pooled analysis at the federal level. We use state fixed effects to control for a state's industry structure. Depending on the industry structure, one might well hypothesize that legislators support an extended tort system to redistribute damage awards from out-of-state industries to home-state consumers. Citizens in these states might also send more attorneys to Congress, which would lead to confounded estimates of the effect of a legislator's professional background as an attorney on the probability of voting against a restriction of tort liability. Moreover, we control for bill fixed effects in all pooled analyses at the federal and state levels. In addition to accounting for distinct legal aspects of certain bills (and the state in the case of state-level votes), the inclusion of bill fixed effects also controls for the timing of the bills and the votes. At the state level, we include bill fixed effects to take into account that attorneys in state legislatures with many lawyer-legislators might support reforms less than their colegislators but still generally more then lawyer-legislators in states where lawyerlegislators form a small minority. Without bill fixed effects, this constellation might spuriously lead to a reverse effect.

The default maximum likelihood estimation of different specifications of equation (2) based on our data set implies, in some cases, a nonidentifiability problem due to complete separation. The separation arises because some explanatory variables (or linear combinations of them) are perfectly predictive of voting yes or no. For example, at the federal level, the sole representative of Alaska always voted yes; hence, the state indicator Alaska is a perfect predictor of voting yes. Nonidentifiability due to (quasi-)complete separation in the data is well known in the econometrics literature; it is, however, often ignored in applied research. Similar to the problem of multicollinearity, the separation problem leads to es-

\footnotetext{
${ }^{22}$ In addition, we cross-checked our results for both the federal and the state level by reestimating our main specifications on samples that contain each legislator only once. This ensures that we do not overestimate the statistical significance of the findings because of repeated votes by the same individuals. The results of these additional analyses were qualitatively very similar to our baseline results and are available on request.
} 
sentially meaningless results (maximum likelihood estimates from a logit model with [quasi-]complete separation are simply a function of the iteration procedure). It could be argued that removing observations of Alaska's representative from the sample is a reasonable approach to dealing with this problem (but it would mean removing potentially important information from the sample). However, the problem also arises in some estimations using individuals' characteristics (for instance, because in some votes at the state level all attorneys voted against the reform). Removing these observations from the sample is for obvious reasons not a sound solution to the separation problem. To overcome this problem, we apply the approach suggested in Gelman et al. (2008) to estimate the coefficients of the logit models. ${ }^{23}$ The estimated coefficients can be interpreted like those from the usual logit model. For several of them, we calculate discrete effects on the probability of voting in favor of a reform. ${ }^{24}$ This facilitates their interpretation and allows a comparison with the OLS estimates. We report discrete effects as the mean of all individual differences in predicted probabilities in the sample. For all observations we thus set Attorney equal to one and then to zero, computing the predicted probability of voting yes for both cases and averaging over all the differences between the two predicted probabilities of voting yes. Formally, this can be expressed as

$$
\frac{1}{n} \sum_{i=1}^{n}\left[F\left(\boldsymbol{x}_{i}^{\prime} \hat{\boldsymbol{\beta}} \mid x_{i l}=1\right)-F\left(\boldsymbol{x}_{i}^{\prime} \hat{\boldsymbol{\beta}} \mid x_{i l}=0\right)\right],
$$

where $F$ denotes the cumulative density function of the logistic distribution, $\boldsymbol{x}_{i}$ is a vector of explanatory variables describing observation $i, \boldsymbol{\beta}$ is a vector of the esti-

\footnotetext{
${ }^{23}$ Gelman et al. (2008, p. 1363) present a default logistic model for routine use by applied researchers that is "better than the unstable estimates produced by the current default-maximum likelihood." The method of Gelman et al. (2008) is essentially an adoption of the classical maximum likelihood algorithm and assigns independent Cauchy prior distributions to all logistic regression coefficients with center 0 and scale set to 2.5 to coefficients of binary predictors, $2.5 /(2 \times$ standard deviation of the numerical predictor) to coefficients of numerical predictors, and scale 10 to the constant term. Like the default maximum likelihood estimator for logit models, this alternative algorithm computes point estimates and standard errors. The method is, however, robust to (quasi-) complete separation and thus produces always meaningful results. Gelman et al. (2008) demonstrate the effectiveness of their method with a model predicting the probability of a Republican vote for president depending on a voter's demographic characteristics. In cases in which no complete separation exists in our analyses and estimation using default maximum likelihood regression is feasible, we cross-check the coefficients obtained from Gelman et al.'s method with those estimated with default maximum likelihood regression. The results are qualitatively the same and often close to numerically identical. For reasons of simplicity, we therefore present in all applications of logit models in this study only the coefficients estimated with the robust method.

${ }^{24} \mathrm{We}$ favor discrete effects over marginal effects for two reasons. First, applying the partial derivative formula to estimate marginal changes in probabilities in a logit model can yield nonsensical results that violate the rule that probabilities should sum to 1 (Caudill and Jackson 1989). Second, in our setting the explanatory variables of most interest are all binary, and computing the effect of an infinitesimal change of such variables can be highly inaccurate (Winkelmann and Boes 2006) and, with regard to content, inappropriate (namely, the effect of an infinitesimal change in having a professional background as an attorney).
} 
mated coefficients, and $x_{i l}$ is the indicator variable of interest (such as Attorney). ${ }^{25}$ Using our empirical strategy, we first analyze attorneys' differential voting behavior. We then discuss a series of robustness checks and complementary tests of the private-interest hypothesis.

\section{Results}

We present our main results separately for reform bills at the federal and state levels. In addition, we present federal-level estimations based on subsamples containing only Democrats or Republicans. We primarily test whether attorneys are statistically significantly less likely than nonattorneys to vote for reforms that restrict tort litigation (or more likely to support extensions of tort law). Our focus is on estimates based on pooled data from many votes. However, we also estimate results for single votes to check whether the general findings are driven by one or very few of the votes. In complementary analyses, we test alternative explanations and simulate voting results assuming a strict recusal rule.

\subsection{Tort Reform Bills at the Federal Level}

Table 3 presents the results based on 12 votes on bills in the House of Representatives and two votes in the Senate. All estimations include state and bill fixed effects. According to the OLS estimation in specification (1), attorneys are 7.3 percentage points less likely than nonattorneys to vote in favor of reforms. The effect is highly statistically significant and supports the hypothesis that lawyerlegislators exhibit a distinct voting behavior that is in line with the profession's business interest. The effect holds, ceteris paribus. In particular, Republicans are around 84.6 percentage points more likely than Democrats to support reform bills. Moreover, female legislators are less likely than their male colleagues to support tort reforms. (The estimated coefficient is -3.5 percentage points.) No statistically different voting behavior is observed for older people or those with a higher level of education. Interestingly, legislators who have a degree from a law school but are not practicing law are not less likely to support reforms. While the finding has to be put in perspective given the sample of 122 votes from 29 representatives, it suggests that studying law does not generally motivate legislators to vote against reforms.

The reestimation of the baseline model using a logit regression indicates that the main findings are robust to the estimation method. As the logit coefficients cannot be interpreted directly, we report effects calculated as the mean of all discrete differences in probabilities in our sample. ${ }^{26}$ While the baseline probability that nonattorneys will support reform bills is .572 , the probability is .504 , or 6.8

\footnotetext{
${ }^{25}$ On the basis of the arguments presented in Hanmer and Kalkan (2013), we prefer this approach over presenting discrete effects for a typical (average) observation. To make our results fully comparable with other studies, we also report for our main results the size of discrete effects for the average observation.

${ }^{26}$ Figure B2 in the online appendix illustrates how the individual discrete effects are distributed in our samples.
} 
Table 3

Federal Tort Reform Votes by Sample

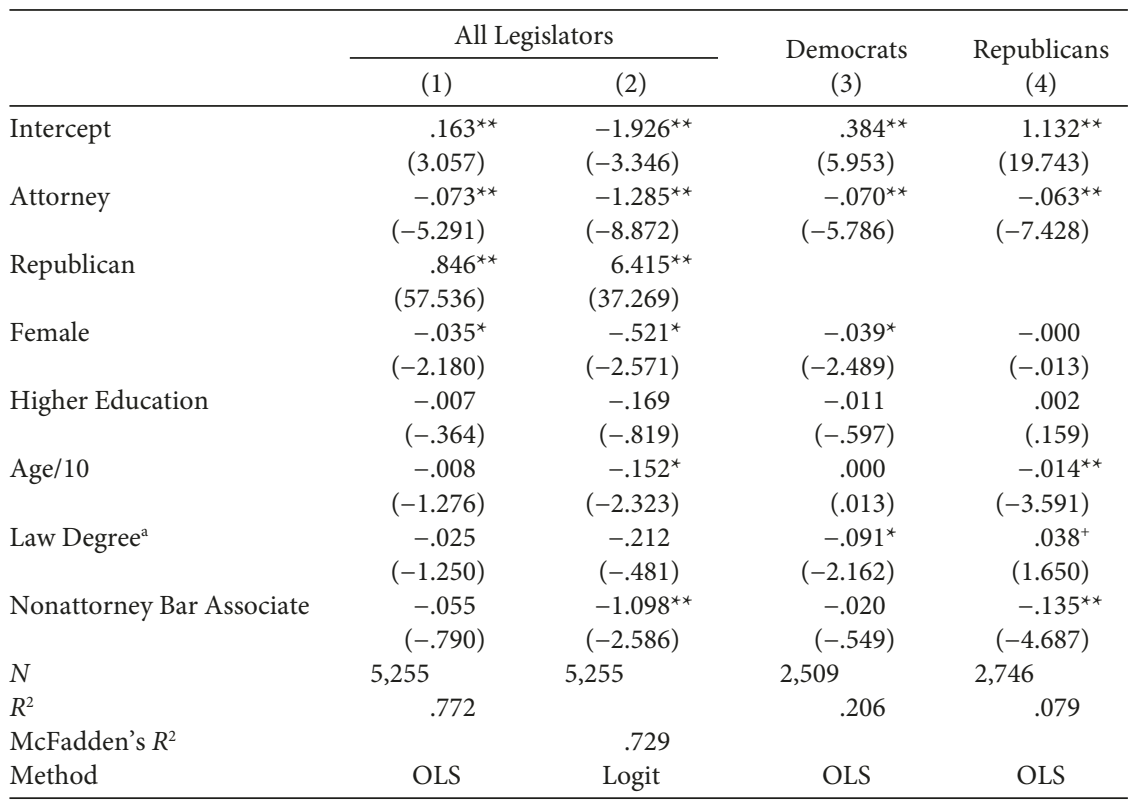

Note. Values are the results of ordinary least squares (OLS) or logit specifications using pooled data. Standard errors of the OLS specifications are clustered at the individual level; $t$-values (OLS) or $z$-values (logit) are in parentheses. The dependent variable is a vote in favor of reform. The logit models are estimated with the method suggested by Gelman et al. (2008) to avoid the separation problem that would occur with the default maximum likelihood estimator. All specifications include state and bill fixed effects.

${ }^{a}$ Not an attorney or member of a bar.

$+p<.10$.

${ }^{*} p<.05$.

${ }^{* *} p<.01$.

percentage points lower, for attorneys. The difference between Republicans and Democrats is 84.7 percentage points. Associates of the bar for whom no law practice is observed (Nonattorney Bar Associates) follow attorneys in their voting behavior. According to the logit specification, the votes of attorneys and their fellow interest group members are thus aligned. Finally, female legislators are 2.7 percentage points less likely than male legislators to support tort reforms according to this alternative estimation approach. ${ }^{27}$ In two additional specifications, we estimated OLS models separately for samples of Democrats and Republicans. The results indicate that the voting behavior of attorneys in both parties deviates systematically from that of their fellow members. The estimated coefficients of -7.0

${ }^{27}$ Discrete effects based on the average observation are substantially larger. According to this alternative measure, the difference in the probability of voting in support of a reform bill is -29.85 percentage points for attorneys, 91.51 percentage points for Republicans, and -12.45 percentage points for women. 
Table 4

State-Level Tort Reform Votes by Type of Bill

\begin{tabular}{lccccc}
\hline & \multicolumn{2}{c}{ Restricting Tort Law } & & \multicolumn{2}{c}{ Extending Tort Law } \\
\cline { 2 - 3 } \cline { 5 - 6 } & $(1)$ & $(2)$ & & $(3)$ & $(4)$ \\
\hline Intercept & $.102^{* *}$ & $-2.805^{* *}$ & & $.968^{* *}$ & $3.025^{* *}$ \\
Attorney & $(6.663)$ & $(-7.749)$ & & $(11.126)$ & $(5.764)$ \\
& $-.069^{* *}$ & $-1.180^{* *}$ & & $.079^{*}$ & $1.099^{* *}$ \\
Republican & $(-4.435)$ & $(-5.026)$ & & $(2.256)$ & $(3.055)$ \\
& $.837^{\star *}$ & $6.575^{* *}$ & & $-.826^{* *}$ & $-5.310^{* *}$ \\
Female & $(72.219)$ & $(25.469)$ & & $(-34.273)$ & $(-17.168)$ \\
& .004 & .014 & & $.060^{* *}$ & $.840^{*}$ \\
Higher Education & $(.306)$ & $(.067)$ & & $(3.041)$ & $(2.547)$ \\
& .012 & .263 & & -.000 & .039 \\
Law Degree & $(1.037)$ & $(1.367)$ & & $(-.005)$ & $(.136)$ \\
& -.035 & -.528 & & .049 & .453 \\
Nonattorney Bar Associate & $(-.637)$ & $(-.666)$ & & $(.359)$ & $(.409)$ \\
& $-.080^{+}$ & -1.017 & & .171 & $1.640^{+}$ \\
$N$ & $(-1.851)$ & $(-.843)$ & & $(.945)$ & $(1.855)$ \\
$R^{2}$ & 2,742 & 2,742 & 853 & 853 \\
McFadden's $R^{2}$ & .744 & & .711 & .699 & .632 \\
Method & & OLS & Logit & & OLS \\
\hline
\end{tabular}

Note. Values are the results of ordinary least squares (OLS) or logit specifications using pooled data. Standard errors of the OLS specifications are clustered at the individual level; $t$-values (OLS) or $z$-values (logit) are in parentheses. The dependent variable is a vote in favor of reform. The logit models are estimated with the method suggested by Gelman et al. (2008) to avoid the separation problem that would occur with the default maximum likelihood estimator. All specifications include bill fixed effects. Legislators' ages are not available at the state level.

${ }^{a}$ Not an attorney or member of a bar.

$+p<.10$.

${ }^{*} p<.05$.

$* * p<.01$.

percentage points for Democrats and -6.3 percentage points for Republicans are of similar magnitude. ${ }^{28}$

Tables B5 and B6 in the online appendix show that the findings for the pooled data are not driven by single votes. For 13 of the 14 bills at the federal level, we find that attorneys are less likely than nonattorneys to support them. In seven cases, the partial correlation is also statistically significant. For the variable for party affiliation, we find strong positive effects for Republicans throughout. For female legislators, the estimated support of reforms is statistically significantly lower than for male legislators in seven cases.

\subsection{Tort Reform Bills at the State Level}

Results for state-level tort reforms based on pooled data are presented in Table 4. The baseline specification shows similar results for the state and federal levels.

${ }^{28}$ If instead an interaction term between Attorney and party affiliation is included, the baseline effect for attorneys from the Democratic Party is $-.066(t=-3.24)$, and the linear combination for Republican attorneys is $-.079(t=-7.41)$. 


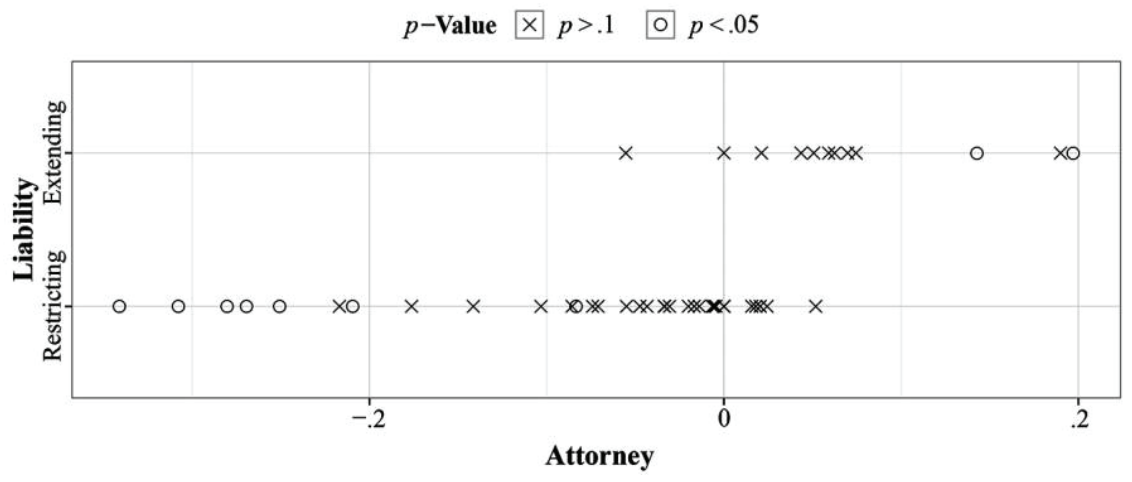
votes.

Figure 2. Distribution of marginal effects for the variable Attorney for individual state-level

Attorneys are less likely than nonattorneys to support bills that restrict tort law. The estimated statistically significant effect is -6.9 percentage points. Republicans are 83.7 percentage points more likely than Democrats to support restricting reforms. Unlike at the federal level, female legislators do not vote significantly differently from male legislators. Level of education seems also not to make a difference for voting on tort issues.

The main results hold if the theoretically more appropriate logit estimator is used. According to the discrete effects based on the coefficients in specification (2), attorneys are on average 6.7 percentage points less likely and Republicans are 83.6 percentage points more likely than nonattorneys and Democrats to support restricting tort reforms at the state level.

For the 12 votes on bills that proposed an extension of tort law at the state level, the results in specifications (3) and (4) reveal an inversion of the partial correlations consistent with the central hypothesis of our study. The coefficients of the linear model indicate that attorneys are 7.9 percentage points more likely than nonattorneys to support an extension of tort law. The probability that Republicans support it is 82.6 percentage points lower than that of Democrats. Consistent with the idea that women benefit relatively more from an extended tort law, results for female legislators indicate increased support by 6.0 percentage points. The effects based on the logit model in specification (4) are all qualitatively the same and quantitatively very similar. ${ }^{29}$

The generality of the main result for attorneys across individual votes at the state level is presented in Figure 2. Attorney coefficients from linear models individually estimated for each of the roll call votes at the state level are plotted

\footnotetext{
${ }^{29}$ The effects computed for the average observation are again larger. In the case of restricting reforms at the state level, the difference in the probability of voting in support of a reform bill is -22.54 percentage points for attorneys and 91.36 percentage points for Republicans. In the case of extending reforms, the difference in the probability of voting in support of a reform bill is 22.63 percentage points for attorneys, -86.73 percentage points for Republicans, and 18.19 percentage points for female legislators.
} 
separately for 12 bills that involve an extension and for 38 bills that involve a restriction of tort law. The distribution of the marginal effects clearly shows that for extensions of tort law, support by attorneys is identical or higher in all but one case. For bills that proposed a restriction of tort law, attorneys in most cases are less likely than nonattorneys to vote yes. There are only five cases in which the effect is small and positive (but none are statistically significant). These results are not only congruent with our hypothesis that lawyer-legislators vote on tort issues in favor of the legal services business, but they also contradict the prevalent theory that lawyer-legislators' actions in office are conservative and mainly aimed at defending the status quo. Even though the lawyer-legislators' voting on typical bills restricting tort liability might be interpreted as a preference toward the status quo, this does not at all hold for bills that extend tort liability.

\subsection{Hypothetical Voting Results Assuming a Strict Recusal Rule for Attorneys}

To provide an assessment of the material importance of attorneys' voting behavior (being indicative of their influence on committees and the legislative process in general), we conduct an exploratory simulation of the possible vote outcomes if there were a strict recusal rule applied to attorneys for legislation involving tort law (see the online appendix for some further comments and data). Thereby, we have to ignore reactions and dynamics resulting from a strict recusal rule. While at the federal level, the outcomes for the 10 bills that passed would not have been different, at the state level outcomes would have been different: 37 instead of 35 (of the 38) bills that restrict tort law would have passed. With regard to bills that extended tort law, only 9 of the 12 reform bills would have been approved. Lawyer-legislators thus were pivotal in five of 50 cases at the state level.

\subsection{Tests of Alternative Explanations}

The results shown above clearly indicate that lawyer-legislators' voting on tort issues is distinct from that of legislators with different professional backgrounds. The partially differential voting behavior of legislators with a law degree, but not practicing law, moreover suggests that lawyer-legislators' voting behavior cannot simply be ascribed to their superior knowledge of the law. Instead of reflecting private interests, the results may, however, also come about because lawyerlegislators vote differently in general or cater to their constituents. We explore these alternative explanations in supplementary analyses (described in detail in the online appendix) and present here a summary of the findings.

Are Lawyer-Legislators Simply Different? Attorneys might generally vote differently from other legislators on various issues including tort law. While such an explanation runs counter to the existing empirical literature on the general voting behavior of lawyer-legislators (as discussed in Section 2.2), we directly confront it with our data. First, we analyze whether lawyer-legislators vote systematically differently on various other bills by a magnitude similar to that observed for tort reforms. For this, we consecutively draw 200 samples at the federal and state lev- 
els using a random selection of bills included in Project Vote Smart's data and estimate our logit baseline specifications (as in Tables 3 and 4). The results indicate that it is possible to obtain some statistically significant coefficients for attorneys in arbitrary sets of votes on various issues. The size and statistical significance of the coefficients, however, never come close to those of the coefficients in our original analyses. The voting behavior of lawyer-legislators that we observe in votes on tort law issues thus cannot be explained by lawyer-legislators voting differently in general.

Second, we test whether the difference in voting behavior can be statistically accounted for by lawyer-legislators' full roll call records. The stance on tort reforms might reflect a general political orientation that characterizes lawyerlegislators independent of their specific business interests. Accordingly, we include the well-known DW-NOMINATE roll call measure as a proxy for ideology in our specifications at the federal level. The OLS results indicate that legislators who are 1 standard deviation more conservative than average support a restricting tort reform proposal with a probability that is 21.1 percentage points higher (statistically significant at the 1 percent level). ${ }^{30}$ Moreover, the indicator Attorney remains an important explanatory factor both in magnitude and in statistical significance. In the OLS estimation, the effect amounts to 6.1 percentage points (relative to the 7.3 percentage points in the baseline estimation in Table 3). The difference in lawyer-legislators' voting on tort issues thus cannot be statistically accounted for by their full roll call records.

Third, we study whether the voting pattern is more pronounced for lawyerlegislators who indicate recent activity as attorneys than for those who practiced less recently. Evidence in this direction might suggest that differences in voting behavior are due to business interests. Accordingly, we divide the attorneys into two groups: those mentioning occupation as attorney as the most recent professional activity in their biographical records and those mentioning any occupation as attorney either longer ago or not as the primary occupation. While recently active attorneys are 7.7 percentage points more likely than nonattorneys to support an extended tort law, the effect for the other attorneys is 4.4 percentage points. This pattern fits the interpretation that it is private economic interest rather than a generally higher faith in the tort system that drives the differential voting behavior.

Do Lawyer-Legislators Follow Voter Preferences? Whether attorneys in politics happen to cater with their voting decisions to voter preferences opposing tort reforms independent of their private interests is inherently difficult to judge. In our empirical analysis of Congress, we control in a most flexible way for variation in tort-specific policy preferences across states and include state fixed effects. However, there might still be specific voter preferences reflected in the election

\footnotetext{
${ }^{30}$ The gender difference is no longer sizable and statistically significant when controlling for legislators' full roll call records. This suggests that there are no gender-specific effects on voting on tort reforms that go beyond what is captured in such an ideology measure (reflecting women legislators' generally more liberal positions).
} 
of an attorney that characterize an electoral district independent of, for instance, general ideology. We use three tests to approach this alternative explanation. First, using the idea of narrow election results exploited in regression discontinuity designs such as in Lee (2001), we compare the voting behavior of lawyerlegislators who won election against nonattorney candidates with the voting behavior of nonattorneys who won election against attorney candidates by narrow margins. If these constellations capture similar underlying voter preferences, no systematic difference in voting patterns on tort reforms is expected. However, the estimation results reveal a highly statistically (and economically) significant negative effect for attorneys in all of the specifications. This evidence suggests that our findings are not driven by differences in voter preferences.

Second, in a similar test, we ask whether nonattorneys facing attorney challengers are less likely to vote in favor of restricting tort reforms. In particular, this is presumed to be the case if an election was won by a small margin, which indicates that the candidates had positioned themselves ideologically close to each other. However, we do not find any evidence supporting this alternative explanation. For legislators running against attorneys, a small statistically insignificant partial correlation is observed that is driven not by the close races but by those with clear nonattorney winners.

Third, in an illustrative analysis, we explore whether lawyer-legislators vote differently when not facing reelection incentives because of term limits. Using data from the four states in our data set with lifetime term limits, we find a small statistically insignificant positive effect of 4.1 percentage points for attorneys who can run again and a large statistically significant positive effect of 6.8 percentage points for attorneys who face a binding term limit. The illustrative evidence is consistent with a refined hypothesis that the pursuit of private interests is more likely when facing weaker electoral incentives. In addition, the phenomenon of attorneys' voting behavior overall cannot be explained by specific voter preferences.

\section{Concluding Remarks}

Attorneys elected to Congress and to state legislatures are systematically less likely than nonattorneys to vote in favor of tort reforms that restrict tort litigation but are more likely to support bills that extend tort law. This finding is based on an analysis of 14 votes at the federal level and 50 votes at the state level (or 8,850 decisions of individual legislators) between 1995 and 2014. The empirical regularity is consistent with our hypothesis that lawyer-legislators, at least in part, vote in line with attorneys' business interests when they vote on tort issues. A set of alternative explanations is explored that, however, cannot account for the observed pattern in voting behavior. In addition, we find that legislators from the Republican Party are more in favor of restricting tort law. Finally, women in Congress support restricting tort reform bills systematically less than men, ceteris paribus. This difference, however, can be accounted for by their individual roll call records on other bills as captured in a measure of ideology. 
In a broader perspective, our findings highlight the relevance of legislators' identities and individual professional interests for economic policy making. Legislatures should thus not be understood solely as platforms where policy preferences of constituents and special interest groups are balanced. It matters how institutions shape incentives for citizens to pursue a political career and for parties to nominate candidates with particular characteristics. In our context, institutional factors that narrow the lawyer-legislators' discretionary scope of action and/or affect the demand and supply of lawyers for political mandates might well affect the substance of tort law. Recusal rules and ethics laws in general aimed at limiting lawyer-legislators' conflicts of interest are in force in Congress and many state legislatures, but their merit and effectiveness is far from clear (Carpinello 1989). Furthermore, little is known about the institutional determinants of the representation of lawyers in politics (for an exception, see Rosenson 2006).

Our work suggests further research in at least two directions. First, in terms of methods, we believe that data from souerces such as Project Vote Smart offer great potential for quantitative research (or data-driven computational social science; see Lazer et al. 2009) in areas such as political economics, political science, and empirical legal studies. The data allow fully reproducible research in terms of data collection, data editing, and data analysis. Studies can relatively easily be replicated and extended with additional waves of data such as new voting records. Moreover, new opportunities arise for combining accurate data sources on individual politicians' behavior and their identities. Second, in terms of substance, it might be worthwhile to further explore tort law as endogenous to the political process. What are the determinants of tort reforms? This might help to disentangle economic outcomes attributed to tort law from underlying political forces. 


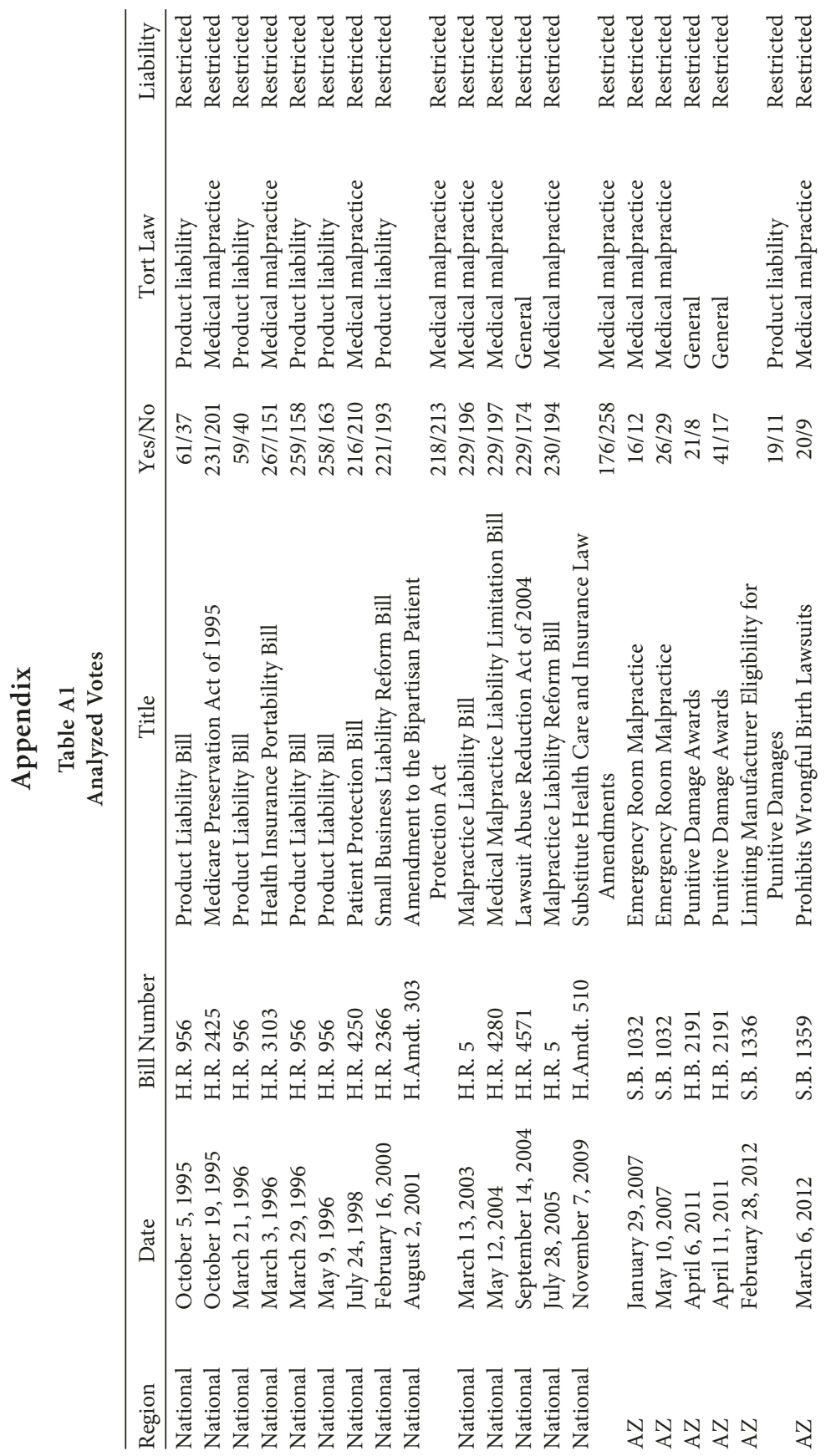




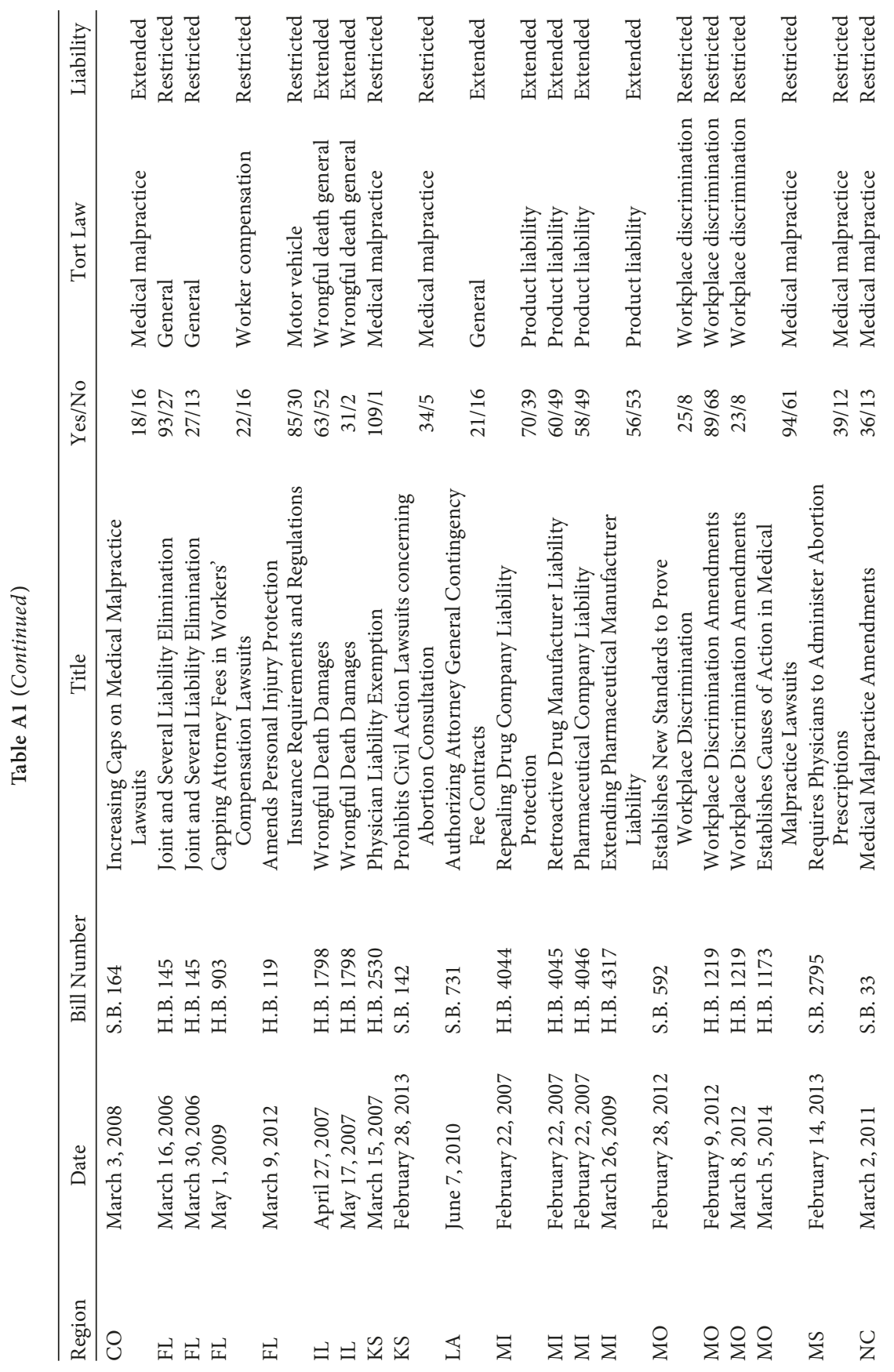



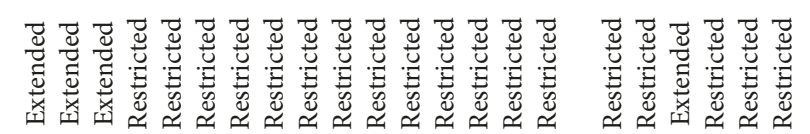

芴苛

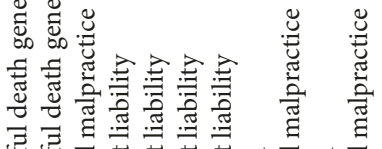

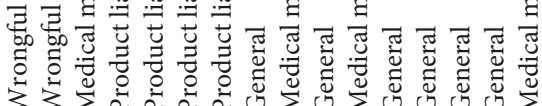

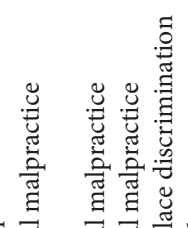

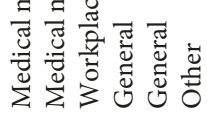

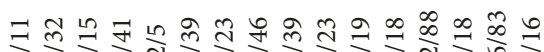

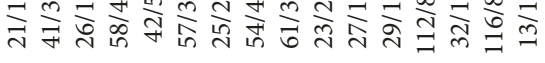

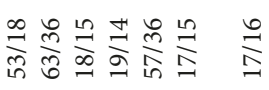
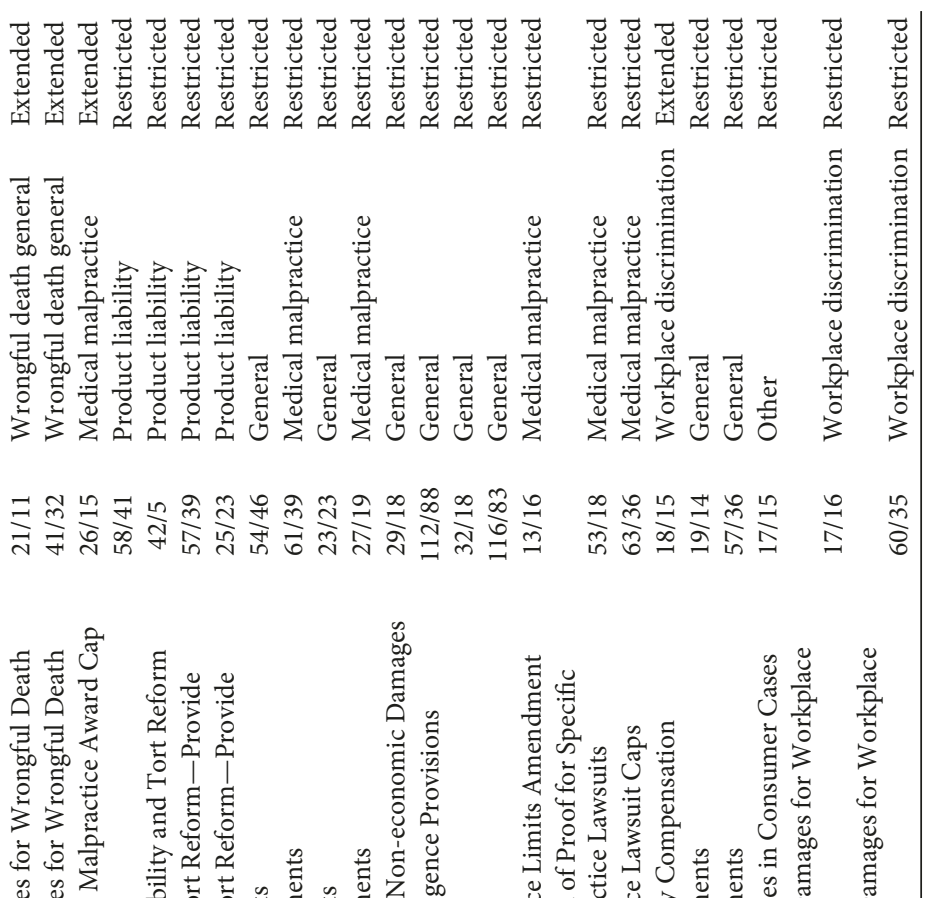

苛 :

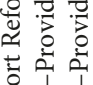

- 1

두유.

$\approx \widetilde{\mathscr{a}}$

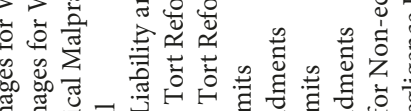

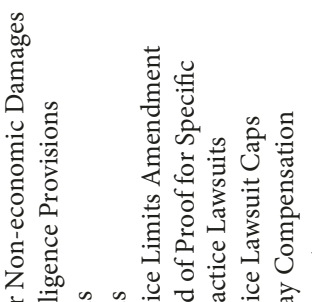

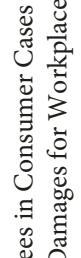

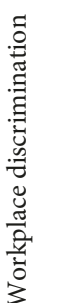

กิ

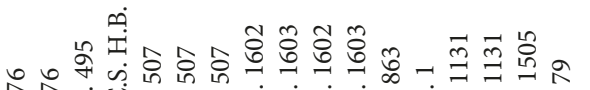

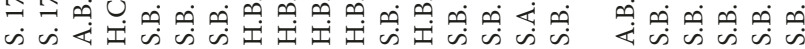

完客

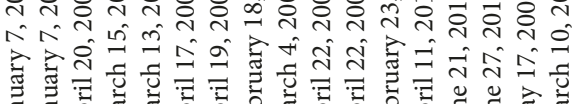

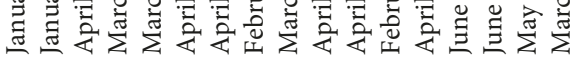

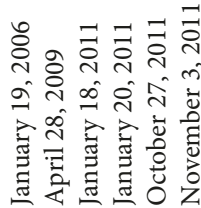

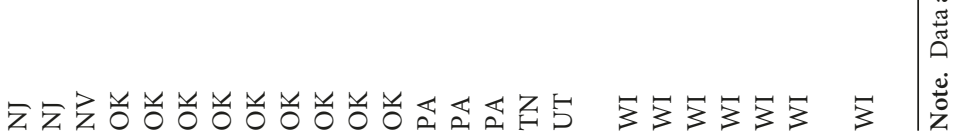




\section{References}

Ai, Chunrong, and Edward C. Norton. 2003. Interaction Terms in Logit and Probit Models. Economics Letters 80:123-29.

Avraham, Ronen. 2007. An Empirical Study of the Impact of Tort Reforms on Medical Malpractice Settlement Payments. Lournal of Legal Studies 36:S183-S229.

Besley, Timothy. 2005. Political Selection. Iournal of Economic Perspectives 19(3):43-60.

Besley, Timothy, and Stephen Coate. 1997. An Economic Model of Representative Democracy. Ouarterlv Journal of Economics 112:85-114.

2003. Elected versus Appointed Regulators: Theory and Evidence. Lournal of the European Economic Association 1:1176-1206.

Braendle, Thomas, and Alois Stutzer. 2010. Public Servants in Parliament: Theory and Evidence on Its Determinants in Germany. Public Choice 145:223-52.

- 2011. Selection of Public Servants into Politics. Discussion Paper No. 2011/06. University of Basel, Department of Business and Economics, Basel.

Carpinello, George F. 1989. Should Practicing Lawyers Be Legislators? Hastings Law Journal 41:87-130.

Caselli, Francesco, and Massimo Morelli. 2004. Bad Politicians. Lournal of Public Economics 88:759-82.

Caudill, Steven B., and John D. Jackson. 1989. Measuring Marginal Effects in Limited Dependent Variable Models. Journal of the Royal Statistical Society: Series D 38:203-6.

Chattopadhyay, Raghabendra, and Esther Duflo. 2004. Women as Policy Makers: Evidence from a Randomized Policy Experiment in India. Econometrica 72:1409-43.

Derge, David R. 1959. The Lawyer as Decision-Maker in the American State Legislature. Iournal of Politics 21:408-33.

. 1962. The Lawyer in the Indiana General Assembly. Midwest Journal of Political Science 6:19-53.

de Tocqueville, Alexis. 1838. Democracy in America. 2nd American ed. New York: G. Dearborn.

Dyer, James A. 1976. Do Lawyers Vote Differently? A Study of Voting on No-Fault Insurance. Journal of Politics 38:452-56.

Eisenberg, Theodore, and Geoffrey P. Miller. 2004. Attorney Fees in Class Action Settlements: An Empirical Study. Journal of Empirical Legal Studies 1:27-78.

Engstrom, Richard L., and Patrick F. O'Connor. 1980. Lawyer-Legislators and Support for State Legislative Reform. Iournal of Politics 42:267-76.

Epstein, Richard A. 1988. The Political Economy of Product Liability Reform. American Economic Review 78:311-15.

Finley, Lucinda M. 2004. The Hidden Victims of Tort Reform. Emory Law Journal 53: 1263-1314.

Gagliarducci, Stefano, Tommaso Nannicini, and Paolo Naticchioni. 2010. Moonlighting Politicians. Journal of Public Economics 94:688-99.

Gehlbach, Scott, Konstantin Sonin, and Ekaterina Zhuravskaya. 2010. Businessman Candidates. American Journal of Political Science 54:718-36.

Gelman, Andrew, Aleks Jakulin, Maria Grazia Pittau, and Yu-Sung Su. 2008. A Weakly Informative Default Prior Distribution for Logistic and Other Regression Models. Annals of Applied Statistics 2:1360-83.

Goldberg, John C., and Benjamin Zipursky. 2010. The Easy Case for Products Liability Law: A Response to Professors Polinsky and Shavell. Harvard Law Review 123:1919-48. 
Graves, William Brooke. 1946. American State Government. 3rd ed. Boston: Heath.

Green, Justin J., John R. Schmidhauser, Larry L. Berg, and David Brady. 1973. Lawyers in Congress: A New Look at Some Old Assumptions. Western Political Quarterly 26:44052.

Hadfield, Gillian K. 2000. The Price of Law: How the Market for Lawyers Distorts the Justice System. Michigan Law Review 98:953-1006.

Hain, Paul L., and James E. Piereson. 1975. Lawyers and Politics Revisited: Structural Advantages of Lawyer-Politicians. American Journal of Political Science 19:41-51.

Handberg, Roger B., Jr. 1976. The 1974 Term of the United States Supreme Court. Western Political Quarterly 29:298-312.

Hanmer, Michael J., and Kerem Ozan Kalkan. 2013. Behind the Curve: Clarifying the Best Approach to Calculating Predicted Probabilities and Marginal Effects from Limited Dependent Variable Models. American Journal of Political Science 57:263-77.

Hyneman, Charles S. 1940. Who Makes Our Laws? Political Science Quarterly 55:556-81.

Klick, Jonathan, and Catherine M. Sharkey. 2008. What Drives the Passage of Damage Caps? Pp. 229-330 in Empirical Studies of Judicial Systems around the Globe, edited by Kuo-Chang Huang. Taiwan: Institutum Jurisprudentiae.

Lazer, David, Alex Pentland, Lada Adamic, Sinan Aral, Albert-László Barabási, Devon Brewer, Nicholas Christakis, Noshir Contractor, James Fowler, Myron Gutmann, Tony Jebara, Gary King, Michael Macy, Deb Roy, and Marshall Van Alstyne. 2009. Computational Social Science. Science 323:721-23.

Lee, David S. 2001. The Electoral Advantage to Incumbency and Voters' Valuation of Politicians' Experience: A Regression Discontinuity Analysis of Elections to the U.S. House. Working Paper No. 8441. National Bureau of Economic Research, Cambridge, MA.

Levitt, Steven D. 1996. How Do Senators Vote? Disentangling the Role of Voter Preferences, Party Affiliation, and Senator Ideology. American Economic Review 86:425-41.

List, John A., and Daniel M. Sturm. 2006. How Elections Matter: Theory and Evidence from Environmental Policy. Quarterly Journal of Economics 121:1249-81.

Luce, Robert. 1924. Legislative Assemblies: Their Framework, Make-up, Character, Characteristics, Habits, and Manners. Boston: Houghton Mifflin.

Matter, Ulrich. 2013. pvsR: An R Package to Interact with the Project Vote Smart API for Scientific Research. R package version 0.2.1. http://CRAN.R-project.org/package=pvsR.

Matter, Ulrich, and Alois Stutzer. 2015. pvsR: An Open Source Interface to Big Data on the American Political Sphere. PLOS ONE 10(7):e0130501.

Mattozzi, Andrea, and Antonio Merlo. 2008. Political Careers or Career Politicians? Iournal of Public Economics 92:597-608.

Miceli, Thomas J., and Michael P. Stone. 2013. The Determinants of State-Level Caps on Punitive Damages: Theory and Evidence. Contemporarv Economic Policv 31:110-25.

Miller, Mark C. 1995. The High Priests of American Politics: The Role of Lawyers in American Political Institutions. Knoxville: University of Tennessee Press.

Norris, Pippa, and Joni Lovenduski. 1995. Political Recruitment: Gender, Race, and Class in the British Parliament. Cambridge: Cambridge University Press.

Osborne, Martin J., and Al Slivinski. 1996. A Model of Political Competition with CitizenCandidates. Quarterly Journal of Economics 111:65-96.

Podmore, David. 1977. Lawyers and Politics. British Journal of Law and Society 4:155-85.

Polinsky, Mitchell, and Steven Shavell. 2010a. A Skeptical Attitude about Product Liability Is Justified. Harvard Law Review 123:1949-68.

- 2010b. The Uneasy Case for Product Liability. Harvard Law Review 123:1437-92. 
Rosenson, Beth A. 2006. The Impact of Ethics Laws on Legislative Recruitment and the Occupational Composition of State Legislatures. Political Research Ouarterlv 59:619-27.

Roth, Andrew, and Jonathan Roth. 1989. Devil's Advocates: The Unnatural History of Lawyers. Berkeley, CA: Nolo Press.

Rubin, Paul H. 2005. Public Choice and Tort Reform. Public Choice 124:223-36.

Rubin, Paul H., and Martin J. Bailey. 1994. The Role of Lawyers in Changing the Law. Iournal of Legal Studies 23:807-31.

Rubin, Paul H., and Joanna M. Shepherd. 2008. The Demographics of Tort Reform. $\underline{R}$ view of Law and Economics 4:591-620.

Schlesinger, Joseph A. 1957. Lawyers and American Politics: A Clarified View. Midwest Lournal of Political Science 1:26-39.

Shapiro, Carl. 1991. Symposium on the Economics of Liability. Iournal of Economic Perspectives 5(3):3-10.

Sharkey, Catherine M. 2005. Unintended Consequences of Medical Malpractice Damages Caps. New York University Law Review 80:391-512.

Shepherd, Joanna M. 2008. Tort Reforms' Winners and Losers: The Competing Effects of Care and Activity Levels. UCLA Law Review 55:905-77.

Sugarman, Stephen D. 2002. United States Tort Reform Wars. University of New South Wales Law Journal 25:849-53.

2006. Ideological Flip-Flop: American Liberals Are Now the Primary Supporters of Tort Law. Pp. 1105-22 in Essays on Tort, Insurance, Law, and Society in Honour of Bill W. Dufwa, edited by Hugo Tiberg and Martin Clarke. Stockholm: Jure AB.

Swers, Michele. 2001. Understanding the Policy Impact of Electing Women: Evidence from Research on Congress and State Legislatures. PS: Political Science and Politics 34:217-20.

Towers Watson. 2012. U.S. Tort Costs Trends 2011 Update. New York: Towers Watson.

US Council of Economic Advisers. 2004. Economic Report of the President. Washington, DC: US Council of Economic Advisers.

Warren, Charles. 1911. A History of the American Bar. Boston: Little, Brown \& Co.

Washington, Ebonya L. 2008. Female Socialization: How Daughters Affect Their Legislator Fathers' Voting on Women's Issues. American Economic Review 98:311-32.

White, Michelle J. 1992. Legal Complexity and Lawyers' Benefit from Litigation. International Review of Law and Economics 12:381-95.

Winkelmann, Rainer, and Stefan Boes. 2006. Analysis of Microdata. Berlin: Springer.

Zywicki, Todd J. 2000. Public Choice and Tort Reform. Research Paper No. 00-36. George Mason University, School of Law, Fairfax, VA. 